\title{
TRANSFORMING REGIONAL POSITION OF CENTRAL- EASTERN EUROPE IN THE ECONOMIC SPACE OF THE EUROPEAN UNION WITH SPECIAL REFERENCE TO HUNGARY
}

\author{
GÉZA SALAMIN \\ The Central Bank of Hungary, Vice President of the Hungarian Society for Urban \\ Planning, Member of the Europian Council of Spatial Planners \\ E-mail: salamingeza@gmail.com
}

\begin{abstract}
In post socialist countries that now form the eastern member states of the European Union there was a general vision of the society from the early nineties to catch up to the developed West. The dream of reaching the level of western European economic development and living standards was the main driver for economic transition and EU integration. In spite of modest convergence, however, the difference between the West and the East has remained dominant until today, ten years after the EU accession, while the core-periphery duality is also an important economicgeographic dimension in the European single market. The changing relative position of these regions in economic terms and the interrelation between the East and West of the EU is in the focus of this paper. It addresses some specifics of regional economic development of this area and particularly of Hungary at both macroregional and regional levels paying attention to the economic crisis which started in 2007. In most of the eastern bloc, economic transition and EU integration were associated with several challenges and followed by imbalanced regional development as a result of the dominant role of the foreign direct investments in regional development, which led to the territorial concentration and increase of regional inequalities among regions within these countries.
\end{abstract}

Keywords: European Union, economic development, regional development, Eastern Central Europe, Hungary, transition, economic geography

\section{Introduction}

Around 1990, the countries of Eastern Central Europe, including Hungary, chose market economy instead of the centrally planned one, shifted their political orientation to the capitalist Western Europe instead of Moscow, and started integrating to Western Europe, instead of the Council for Mutual Economic Assistance (CMEA), the economic organizing scheme of the eastern bloc. There are no doubts that these political and economic reorientations had very strong support 
from the vast majority of societies that time due to numerous reasons. One key reason was probably of the highest importance, that is, the assumed promise of the economically more successful capitalist world through which these societies might gain better quality of life, reach the welfare level of the western European countries. The dream of catching up to the West became the key motivation for introducing several economic reforms and a sort of fuel to attain the support of the society to accept and sometimes even welcome measures, such as privatization, market liberalization or giving up centrally-secured full employment, which in Hungary, for example, culminated in the loss of 1.5 million jobs in the early nineties. The dream of catching up became a common framework of understanding that induced these countries to follow the patterns of western economies and to quickly internalize the guidelines coming from the institutionalized European Union.

More than a decade has passed since most of the current post socialist member states - Hungary, Poland, Czech Republic, Slovakia, Estonia, Latvia, Slovenia, Lithuania - joined the European Union, followed some years later by Romania, Bulgaria, and recently Croatia. By today, these countries have a wide range of experiences and it is clearly observable that they have had to face several challenges during the transition and their development track is by far not the same as the western economies had experienced earlier. Attaining the level of the Western welfare does not seem evident now, in addition, there are also some other consequential effects of market liberalization and accession to the European integration from the point of regional development. The economic performance and the position in a single market economic space differ strongly among regions within the eastern block and even the regional differences within these countries have increased, sometimes to a radical extent during the last two decades. After twenty years of evolution of these regions, the economic crisis which started in 2008 has generated a new and much quicker dynamics with regionally selective impacts, influencing the position of the whole post-socialist eastern zone and also its regions. It seems that the economic crisis contributed to the rearrangement of the macro-geography of the economic development of the European Union, and influenced the regional inequalities within the countries, too. Nowadays it is important to pay attention to the current impacts, and even more, to the possible further consequences of recent geopolitical events, particularly the conflicts around the Islamic State in the Middle East and North Africa that are bringing about increasing waves of migration. In this rearrangement, the position of the post socialist eastern bloc, including that of Hungary, is also changing.

By addressing these issues, this paper aims to contribute to a better understanding of the changing position of the regions of this eastern EU bloc and particularly of Hungary in the territory of the European single market. It pays particular attention to the core-periphery geography of the EU and the regional concentra- 
tion within the member states of that zone focusing on Hungary. The analysis is based on the databases of Eurostat and the Hungarian Central Statistical Office (KSH), and uses secondary sources, particularly the latest cohesion report of the European Commission (2014), analyses of ESPON program (2005 and 2010) and the Central Bank of Hungary (2014).

\section{The Changing Position of the Eastern Part of the EU}

The EU produces 21-23 per cent of the world gross domestic product, similarly to the United States' performance, though its population of half a billion is 60 per cent more than that of the USA. The contribution of the post-socialist member states to the total EU performance is 7.8 percent, a definite increase compared to 5.5 per cent at the accession year of 2004 . However, it is still a limited progress compared to the 20 per cent share of these countries within the population of the EU. Hungary's contribution to the GDP of the European Union is 0.74 per cent with stagnation or a little fall as a result of negative demographic trends (See Table 1).

Table 1. The share of Hungary and the post socialist EU member states in GDP and population of the European Union (\%) (Data source: Eurostat)

\begin{tabular}{lcc}
\hline & 2004 (\%) & 2014 (\%) \\
\hline $\begin{array}{l}\text { Share of Hungary in the total population of the EU28 } \\
\text { Share of Hungary in the total GDP (at market price) of the EU28 }\end{array}$ & 0.75 & 1.95 \\
$\begin{array}{l}\text { Share of Hungary in the total GDP (PPS**) of the EU28 } \\
\text { Share of the post socialist member states* in the total population } \\
\text { of the EU28 }\end{array}$ & 21.62 & 20.74 \\
$\begin{array}{l}\text { Share of the post socialist member states* in the total GDP (at } \\
\text { market price) of the EU28 }\end{array}$ & 5.46 & 7.89 \\
$\begin{array}{l}\text { Share of the post socialist member states* in the total GDP } \\
\text { (PPS**) of the EU28 }\end{array}$ & 10.88 & 13.41 \\
\hline
\end{tabular}

*Poland, Hungary, Czech Rep., Slovakia, Slovenia, Estonia, Lithuania, Latvia, Romania, Bulgaria, Croatia

** PPS: purchasing power parity

It is a fact that there are significant growth potentials in the less developed eastern zone of the European Union due to its emerging markets where demand is growing, the cost of labor force is low, and the population has an increasing mobility. This zone, which is in a gateway location towards the rapidly growing 
Asian markets has in the long term higher growth rates, and increasing innovation possibilities in production. The recognition of the good business opportunities this region offers for the Western European economies from the early nineties was a key motivation of the eastward extension of the European integration. In the last two decades the eastern bloc has been in a slow but obvious catching-up process in a number of areas such as transport accessibility, GDP growth, received foreign direct investment (FDI) and expansion of trade in goods and services within the group of new member states, the so-called EU-13 (joined in 2004 or later) and between EU-13 and EU-15, the group of older member states (See Figure 1). The process of catching-up, on the other hand, has recently been slowing down.



Figure 1. Evolution of GDP per capita in PPS of the Visegrád four countries in relation to the average of the 28 current EU member states (EU28 = 100\%) (Data source: Eurostat)

Now we must see that the economic disparities between the East and the West still represent the most obvious regional dimension in the European Union. If we consider quality of life, we can still discover an even wider gap between the West and the East than what the GDP (measured by purchasing power parity method) shows. As we can see in figures, for instance in the $6^{\text {th }}$ cohesion report (European Commission, 2014: 93), life expectancy - which is a key indicator of health - is extremely different westward of the former iron curtain than eastward. The Eastern Central European countries made good progress in setting up the system of market economy, but the east-west dichotomy of the European Union remained, although with changing meaning since the post socialist economies are in a weak and sometimes dependent position. The integration to the single market created still-existing 
difficulties. The post socialist countries had carried their negative heritage, such as lack of sufficient capital, the weaknesses of domestic companies to compete in the single market, the rapid loss of their domestic market, and the dependence on foreign capital, and multinational companies. Most of these countries are highly open economies - e.g. Hungary's export is almost the same as its total GDP - with high exposure to global changes and a risk of vulnerability. In such dual organizational structure of the economy, most of the domestic small and medium enterprises taking part in the export oriented production are dependent on the large foreign companies as suppliers. However, not only companies, but also cities, regions, even states depend sometimes extremely on only one or a handful of companies. Such cases are in Hungary the dominant role in the local economies of IBM in Székesfehérvár, of NOKIA in Komárom, of Audi in Győr, of Mercedes production in Kecskemét. These multinational companies can quickly bring a sort of prosperity, but their relocation could finish in crisis as we saw it in some cases, e.g. Székesfehérvár. These regions are attractive more for economic activities with lower added value; while knowledge intensive industries are much less frequent there with the exception of some capital regions. Nowadays the competition among regions is more about the ability to link to and also to anchor higher levels of the so called value chains of economic activities, where the higher value added activities are concentrated, such as innovation or design. Those regions which are attractive locations only for manufacturing - which is a low level in the value chain - could never approach the development level of the core areas of global economy, like some of the western European regions.

Most of the rural regions of the post socialist bloc face severe difficulties in finding their function in the highly integrated EU arena. These regions are typically not able to compete in the highly competitive export markets, while as a consequence of market liberalization and globalization the domestic and local markets have shrunk due to the increased import. This is important because the eastern bloc is less urbanized. In 2014 only 62 per cent of the population of the eight Eastern-Central European member states were living in cities, while this figure is 79 per cent in the EU-15. (United Nations, 2014: 199)

\section{The Impact of the Economic Crisis}

The global financial crisis that started in 2007 and spread in 2008 strongly affected the EU by changing its development path, just like for most of the developed world (see Figure 2). As current analyses of The Central Bank of Hungary revealed, the latest crisis is unlike any previous crises in the world since the Second World War. Although the imbalance in the generation and utilization of income and in the global distribution of savings and investment opportunities 
preceding the current crisis were similar to the imbalances prevailing in the past - as was ultimately reflected in the widening of current account positions - the emergence of protracted current account imbalances of unprecedented magnitude was a novelty, which affected several economic agents and regions simultaneously. (Magyar Nemzeti Bank, 2014: 10) The account imbalances are in strong connection with the debts of countries. The greatest external debt of the global regions was accumulated in the EU. It is alarming that even in 2014 the government debts to GDP ratio increased in the total European Union (EU-28) from 85.5 per cent to 86.8 per cent, although the government deficit could already decrease. The increase of governmental debt has also set serious limits to local and regional authorities, themselves often also indebted.

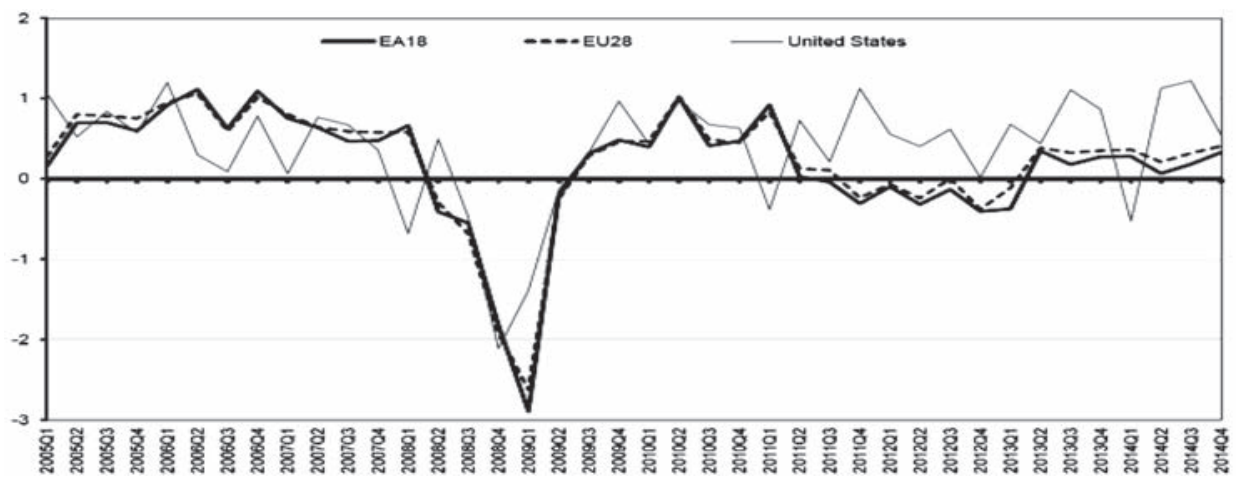

Figure 2. EU28, euro area and United States GDP growth rates (\% change over the previous quarter) (Source: Eurostat, 2015: 1)

Therefore, the current situation in the European Union is dramatically different from what it was at the start of the previous financial period in 2007. As the sixth cohesion report pointed out (European Commission, 2014: XV-XVII), that time the EU was still enjoying a sustained period of economic growth. Income levels were rising as were employment rates and public investment; poverty and social exclusion were diminishing and regional disparities were generally shrinking (at least at the level of countries). The advent of the crisis changed all this. Since 2008, public debt has increased dramatically, income has declined for many people across the EU, employment rates have fallen in most countries and unemployment is higher than for over 20 years while poverty and social exclusion have become more widespread. The shock of the economic depression was territorially very selective. Not only countries, but even regions, different types 
of cities and also main macro regions of the EU showed sensitivity or resistance to very different extents. The onset of the crisis led to major reductions in the EU in trade and foreign direct investment that are important sources of growth for the less developed member states. Exports of the EU-13 to other EU countries, however, have shown significant recovery and now account for a larger share of their GDP than before the crisis, while FDI has also picked up. In most parts of the $\mathrm{EU}$, metropolitan regions have been shown to be more prone to booms and busts, while overall rural regions have proved more resilient. In the EU-15, second-tier metropolitan regions performed near the average, while in the EU-13, they outperformed other regions. Rural regions in the EU-15 had a smaller contraction of GDP than the other regions between 2008 and 2011 due to higher productivity growth. Also, in the EU-13, higher productivity growth meant that they closed the growth gap with the other regions. In transition and less developed regions, increases in unemployment have been larger, averaging 5 percentage points between 2008 and 2013 as against 3 percentage points in more developed regions. (European Commission, 2014: XXX)

Austerity policies, less public funding are influencing the possibilities of regional and urban development as well, and push local actors to do more to regenerate from crisis and foster economic growth at local level. This is why in the EU member states and also at the level of European Union policies focused on growth gained very high importance and other policies have necessarily lost their positions. The experience of the economic crisis and the still existing obvious challenges strongly influence regional, spatial and urban planning policies.

\section{Recent Development of Regions in Eastern Central Europe}

Between 2000 and 2011, all the regions in the central and eastern member states recorded an increase in GDP per head (in PPS) relative to the EU average. The biggest increases were typically in the capital city regions. Indeed, in these regions in Slovakia, Romania and Bulgaria, GDP per head in PPS terms increased markedly (to 186 per cent of the EU average in the first, 122 per cent in the second and 78 per cent in the third), in the first two countries by more than double the national average increase. In the less developed regions in Greece, Italy and Portugal (except the Azores), however, there was no increase in GDP per head relative to the EU average, in Greece due to the severe effect of the crisis, but in the other two, partly to their growth rates being relatively low before the crisis. (European Commission, 2014: 1)

The sixth cohesion report stated that the GDP per head grew faster in real terms in the less developed member states over the period from 2000 to 2013 and is forecast to continue to do so in 2014 and 2015. The rate of growth in the moder- 
ately developed member states, however, fell below that in the highly developed member states in 2010 and continued to be lower in 2011-2013 but is forecast to be slightly higher as to 2015. (European Commission, 2014: 7) If we look at it with the approach from macro geographic dimensions we can state that while the least developed regions in the east could continue their convergence, most of the southern regions - many of them are moderately developed regions - suffered most from the recession.

The cohesion policy of the European Union - allocating 32 per cent of its total budget, the main community level financial support of investments, can be considered as an east-west stabilizing policy, where the net contributors are typically the countries of the more developed West and the main beneficiaries are in the less developed East. It is obvious if we examine the two main funding of cohesion policy: Between 2014 and 2020 all the 182 billion euro of the Cohesion Fund is channeled to the countries having GDP per capita figures less than 90 percent of the EU average, which are all the post socialist member states plus Greece and Portugal, while in case of the Structural Funds, 182 billion euro is allocated to the less developed regions - most of them also located in the eastern zone plus some of them in Portugal, Greece and Southern Italy, while only 54 billion is allocated to the more developed regions of the EU and about 35 billion to the so-called transition regions with 75-90 per cent figures. However, the last reform of the cohesion policy resulted in a more direct control on EU level, by stronger thematic guidance, stricter conditions for member states. It means stronger control over the less developed countries, where the EU funding gives the funds for the vast majority of all public developments. In 2010-2012, Cohesion Policy funding was equivalent to over 75 per cent of public investment in Slovakia, Hungary, Bulgaria and Lithuania and 57 percent in the cohesion countries. During the crisis, the total public investment of member states decreased by 20 per cent in the EU. The rapid reduction of public investment was a part of fiscal consolidation efforts and it brought increased reliance on cohesion policy.

\section{Dependence of Peripheries?}

Based on the World-System Theory of Immanuel Wallerstein and Dependence Theory (Wallerstein, 2010), the core-periphery concept is expansively applied as an obvious tool to understanding the global world, particularly in literatures of sociology and geography. The basic principle of the 'Core-Periphery' theory is that as general prosperity grows worldwide, the majority of that growth is enjoyed by a 'core' region of wealthy countries despite being severely outnumbered in population by those in a 'periphery' that are ignored. In the approach of geography this duality is understood more in the meaning of physical space, where the 
core is really in a center of a given territory. Though it is most frequently used in global context, looking at the spatial distribution of power, economic performance and wealth of regions within the EU we can recognize that this concept does make sense at a European Union scale. The spatial patterns as these characteristics show exhibit clear relation to the geographic center of the EU. According to most of the socio-economic facts the 'good places' are really in the geographical center of the EU. However, this core-periphery relation can be understood in the regional development of countries with strong relation to the monocentric versus polycentric character of socio-economic spatial structures or the spatial distribution of power.

Nearly half of the GDP of the EU is concentrated in a Western core territory called pentagon area, from London to Milan, from Paris to Hamburg, where only one third of the population and 14 per cent of the territory of the EU is located. (Salamin - Sütő, 2011: 50) The core-periphery division of the territory of the EU in development approach was introduced by the expert document of the Hungarian EU presidency entitled "The Territorial State and Perspectives of the European Union” (Salamin - Sütö, 2011: 50-63). As this document pointed out "in general terms the economic as well as the accessibility patterns in Europe are core-periphery centered with the highest peaks in the core of Europe" (Salamin - Sütö, 2011: 50). Although the eastern part of the EU is the most significant periphery, we should mention the other peripheries as well. Periphery can be the northernmost regions of the EU, mainly due to their extremely low population density and lack of bigger, stronger urban centers. In many terms of economic performance, however, the northern part of Europe is on equal footing with the core area and even outperforms it in some indicators. There are western peripheries such as Ireland and also Portugal in many dimensions, while the southern region is rapidly becoming periphery since they suffered at most the economic crisis. Basically, market forces work towards a concentration of economic activities, both at European and national levels. At the same time, there are evidently catching-up processes underway and areas are developing outside the traditional core area. Nonetheless, there are differences even between peripheries: the postsocialist eastern regions are in a quite different position than Europe's western or the less populated northern peripheries. Tendencies suggest that the European core-periphery paradigm shows signs of dissolving. However, these changes are very slow. Centrally located economic concentrations still hold the most advantageous positions.

When addressing the core-periphery division of the EU beyond the issue of economic disparities we also have to mention the issue of dependence of the eastern bloc on the European Union as such (see cohesion policy before), and also on certain more developed western economies. As post socialist countries have not been able to accumulate any sufficient quantity of capital, their GDP 
and especially their export highly depend on the foreign economic agents, while their domestic actors do not have a similar influence on other countries. Not only domestic companies, but also regions and cities of this area have to take part in a strong competition that they are not prepared enough for to compete with other players, particularly to gain better position in the more and more globally organized economic value chains, as mentioned before. Their economies are driven by foreign direct investments that are also the main factor of the development of regions. Obviously the flows of profit also have a similar pattern from the East to the West. Small and highly open economies of the eastern bloc are generally dependent on their main export targets, on the larger markets. In the case of Hungary, the economic performance is directly linked to the German economy, which is the prime foreign trade partner. The dependence of less developed eastern countries on the EU cohesion policy has been already mentioned above. According to the author, the most serious dependency of the east, however, will be seen in the issue of demography (see later in the paper).

\section{Distance to the Core of the EU}

It is reasonable to address the question of what the core is, where the central region of the European Union lies. It is worth seeing whether any regions of the post-socialist countries can be considered as part of this central zone. Beyond the above mentioned pentagon model developed by ESPON program, the geographic center of the EU can be localized in different ways according to factors we are focusing on. Considering the economic power the territory of the center is obviously slightly closer to the west, due to the location of the biggest markets - the UK, France, Germany and the Benelux states. Italy and Spain also have bigger economies but they are still fighting the consequences of the crisis. Nevertheless, as a result of the recent depression the nearly crisis-resistant German economy could strengthen its position, while Poland could take steps towards the central position as its economy hardly suffered from the crisis. Therefore there is a chance that this form of economic core in the EU shifts a bit eastward as a result of the economic shock. According to the innovation activity of the regions the central territory is more extended towards north due to the strong knowledge orientation of the economies of the southern regions of the north of EU. Looking at the intensity of patent applications we see that the area from London to Milan, from Lyon to Stockholm is the innovation core of the EU, where almost all the regions which have more than 150 patent applications a year per million inhabitants are located. (European Commission, 2014: 33) The east is extremely underdeveloped in that regard. It is important to note that economic integration itself increases the potentials of the regions located in the central area of that territory. 
The improvement of physical accessibility within the single market - supported by the transport policies of the EU - naturally contributes to strengthened centerperiphery relations of the EU. Nevertheless, the less significant neighborhood policy provides possibilities to regions along the edge of the Union.

If we understand center-periphery relations in a different way, focusing on the quality of life instead of economic and innovation activity, we find a slightly different, but still definite center-periphery picture, where some regions of the eastern bloc can have more chance to be closer to the center of the EU. In this approach we identify center as the area that has better quality from a human point of view. As we shall see below with this approach the center is shifting eastward. A good example is if we take into account a really periphery-related issue, the risk of becoming poor or excluded. The higher risk of poverty or social exclusion is an important legacy of the economic crisis. In this term, the center - areas with relatively good values - is more extended towards the south-east, for example, the Czech Republic and the north-western part of Hungary are also part of this advantageous core, while the northern part of Germany is outside. (See European Commission, 2014: 75-76) However, looking at the increase of risk of poverty rate we see that the regions geographically far from the center have lost the most. There are now around nine million people at risk of poverty or exclusion in the EU, the increase being particularly pronounced in the geographically peripheral areas, mostly in Greece, Spain, Italy, Ireland, but also in the UK and Sweden and the Baltic states. A key issue is the variation within countries: risk of poverty tends to be much lower in cities than in the rest of the country in less developed member states, while surprisingly in cities in the more developed member states, the reverse is the case. In terms of early school leavers the best center zone of the EU consists of Sweden, Poland, Czech Republic, Slovakia, Lithuania and the southeast part of Germany while the regions westward from this zone (and also eastward) are in significantly worse positions. (See European Commission, 2014: 67)

In general however, the crisis hit the geographically peripheral areas more severely, particularly the Mediterranean zone, thus amplifying the core-periphery division of the EU.

\section{Possible Consequences of Demographic Change}

The natural fertility rate is generally very low in Europe with the exception of France, the Nordic countries, the UK and Ireland. This trend threatens with serious economic outcomes mainly due to the predicted loss of workforce and the radical changes in the ratio between taxpayers and transfer recipients. Demographic trends indicate that the working-age population in the EU-27 started to fall in 2013, and will decrease by around 39 million (12 per cent) by 2050 com- 
pared to 2008. Migrations can be part of the solution to labor market deficits both in qualitative and quantitative terms. Therefore, in the aging Europe facing severe demographic challenges the migration of labor force, which has a clear east-west pattern, is a key factor of development. The very high differences between wages offered in countries with different economic powers means a constant motivation to migrate to work - and later to live - in the western part of the EU (ESPON, 2011). In relation to geopolitical cases in the Middle East, the more developed member states are more likely to prefer eastern European migrants to extra EU migrants. The poorest East may lose the most skilled, educated and ambitious young groups of society, while migration in the opposite direction is less significant. In general economic terms, every wave of migration implies a shift in the knowledge base of both the arrival and the departure country. As migrants carry different skills with them there can be important processes of increasing or declining skills in the labor force (brain gain or brain drain).

\section{Imbalanced Regional Development within the post-Socialist Countries: Regional Polarization is a Side Effect of Transition?}

Having reviewed some regional dimensions at EU level economic processes we now analyze some characteristics of subnational regional development within the countries of the eastern bloc of the European Union and particularly Hungary, identifying the challenge and the possible impact of the crisis. In most of the former socialist countries the period since the EU accession in 2004 commenced with a peculiar, and historically determined, inherited economic spatial structure that has undergone only modest rearrangement during the past ten years. Since the early nineties, the trend of increasing territorial inequalities in the Eastern Central European countries has been closely linked to the process of conversion into market economies and to economic integration to the EU. As mentioned above in this changing economic space, many rural regions in the eastern bloc have lost their perspective, only some bigger cities - mainly capitals - could become international players, while other cities are trying to find their role, but their capability to compete efficiently is questioned in the highly integrated economic arena of the single EU market, itself more and more geographically connected (see Figure 3).

After four decades of centrally planned economy in the socialist era, since 1990 the role of foreign direct investment had been growing increasingly dominant in territorial development as well - through a shift to market economy, market liberalization, and then EU integration - resulting in territorial concentration of the economy by focusing primarily on capital regions along with mainly the western regions. Indeed, in terms of urban size, commercial projects tended to increasingly give preference to sites in larger towns and cities. The faster devel- 
opment of the western parts of these countries can be perceived resulting in an east-west division of the economic space also within the countries.

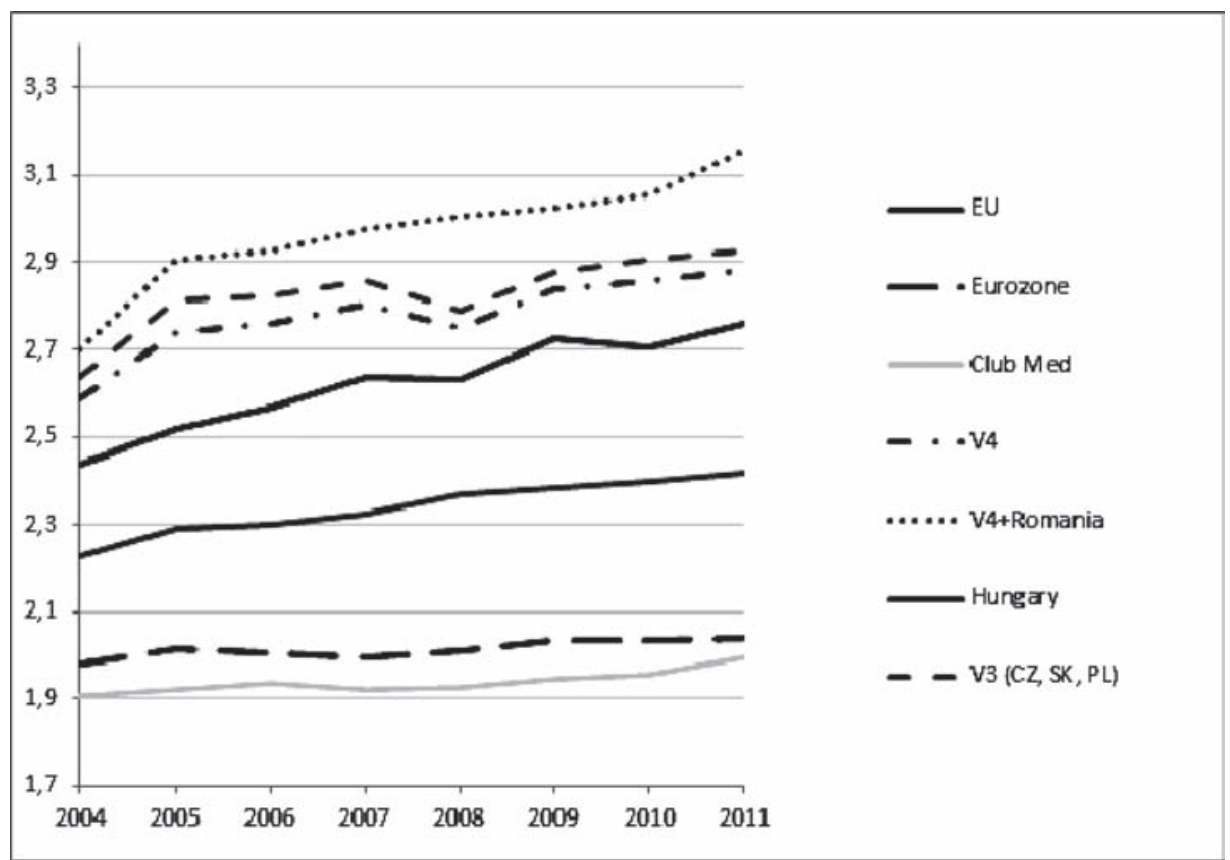

Note: Ratio of the per-capita GDP in the most advanced NUTS2 level region to the least advanced one in the given country, their unweighted average in the various groups of countries. Overseas regions and the states comprising a single region are not taken into account.

Club Med: Greece, Portugal, Italy, Spain

V4: Hungary Poland, Czech Rep., Slovakia

Figure 3. Territorial concentration of GDP within the countries on the basis of their range, 2011 (Based on Eurostat data)

Behind the high regional inequalities, it is important to recognize the lack of sufficient infrastructure in rural areas in these countries. Internal peripheries are unique type of rural peripheries specific to Eastern Central Europe with serious problems. Their peripherality stems primarily from their poor accessibility, and is deepened by the paucity of real urban centers where essential central functions could be concentrated. These problems derive from the historical under-development of these territories and specific features of the settlement network or social characteristics often compound them. The main problems of these areas are their weak and vulnerable regional economies and their lack of appropriate job oppor- 
tunities. In these circumstances, negative demographic processes, notably outmigration and aging of the population, are getting stronger and stronger. These trends create conditions for social exclusion, and even territorial exclusion from mainstream socio-economic processes and opportunities. While rural ghettos are mainly a result of social factors, ethnic segregation can render difficult situations even worse. This is the case, for example, in rural peripheries of Slovakia, Hungary and Romania where there are areas with high proportions of Roma population. This is a non-disappearing specificity of the post socialist Eastern Central Europe, while in the West the social segregation is mainly the challenge of urban areas, emerging particularly in connection with immigrants.

As the cohesion report points out, during the last decade the increase of disparities was particularly high in Bulgaria and in Romania (where the coefficient of variation increased by 22 percentage points and twelve percentage points, respectively), mainly because of the high growth rate in the capital city region. (European Commission, 2014: 5) While GDP per head in the other regions in the two countries still converged towards the EU average, it was at a much slower rate. Regional disparities, however, also widened in Greece and the UK over these eleven years (the coefficient of variation increasing by twelve and eight percentage points, respectively), but in both cases partly because GDP per head declined relative to the EU average in a number of less developed regions.

\section{Increasing Regional Economic Disparities in Hungary}

In comparison to the average of the EU-28 countries and especially in the light of the small size of the country, the internal territorial inequalities are particularly large in Hungary. In longer term the decreasing role of agriculture resulted in the loss of economic weight of regions, which had more agricultural orientation, primarily in the Great Plain during the last decades. The transition crisis in the 1990s hit most the so-called "socialist industrial districts", which is still causing problems in economic development, primarily in the former heavy industry regions of Borsod-Abaúj-Zemplén, Nógrád and Baranya counties. Komárom-Esztergom County, particularly its seat, Tatabánya, is perhaps the only heavy industrial district of the socialist era, which could recover and attain significant economic prosperity. The foreign direct investment, however, had a very concentrated regional preference focusing mainly on Budapest and the north-west of Hungary.

The overall consequence is that territorial inequalities have been growing steadily within Hungary since the mid-1990s, creating severe differences in the levels of development between the capital city and the rest of the country as well as between the eastern and the western part of the country, including a general lag in the development of territories without major cities or towns (see Figure 4). If we 
look at the regional pattern of Hungary's modest convergence to the EU average since the accession, we find that it is in fact the very fast (but slowing) development of Budapest and a modest improvement of the position of Western Transdanubia and the Northern Great Plain, while the other four regions of the country have been showing stagnation or even deteriorating positions (see Table 2).

Table 2. The relative position of Hungarian regions among the 274 regions of the EU28, in terms of per-capita gross domestic product (2011) (Data source: Eurostat)

\begin{tabular}{lcccc}
\hline \multirow{2}{*}{ Region } & \multicolumn{2}{c}{2004} & \multicolumn{2}{c}{2011} \\
\cline { 2 - 5 } & \multicolumn{2}{c}{ GDP/capita PPS } & position in \\
& EU-28=100 & ranking order & $\begin{array}{l}\text { GDP/capita PPS } \\
\text { EU-28=100 }\end{array}$ & $\begin{array}{c}\text { position in } \\
\text { ranking order }\end{array}$ \\
\hline Central-Hungary & 101 & 124 & 110 & 79 \\
Western Transdanubia & 65 & 225 & 68 & 218 \\
Central Transdanubia & 60 & 233 & 59 & 241 \\
Southern Transdanubia & 45 & 251 & 45 & 259 \\
Southern Great Plain & 44 & 252 & 44 & 260 \\
Northern Great Plain & 41 & 256 & 43 & 263 \\
Northern Hungary & 41 & 257 & 40 & 265 \\
\hline
\end{tabular}

The domestic territorial development policy (which was particularly dedicated to tackle less developed regions) and the EU funds, available to Hungary in increasing scale since the accession, have not induced much improvement in the way of reducing the inequalities in economic growth in the various regions; at least no significant results could be observed up to 2010. Although the criterion of regional convergence appeared in the strategies and programs prepared for applying to the utilization of funds, and regional operational programs defined on local levels were launched, the businesses and organizations of the more advanced regions were able to gain access to a greater extent to the funds allocated predominantly through such application schemes. The regional operational programs defined territorially - although they have accomplished significant results for instance in the development of settlements and, in general, in the quick absorption of funds - were not, for the most part, efficiently adjusted to the different conditions and resources of the different regions (which should have been one of their main advantages); accordingly, they remained standardized and typically failed to foster efficient development projects, which could generate significant economic growth in the regions concerned. This was accompanied by a relatively low proportion of the funds dedicated within the structural funds to economic development in the Hungarian operational programs. In the new 2014-2020 period of EU cohesion policy Hungary developed a more economy oriented strategy 


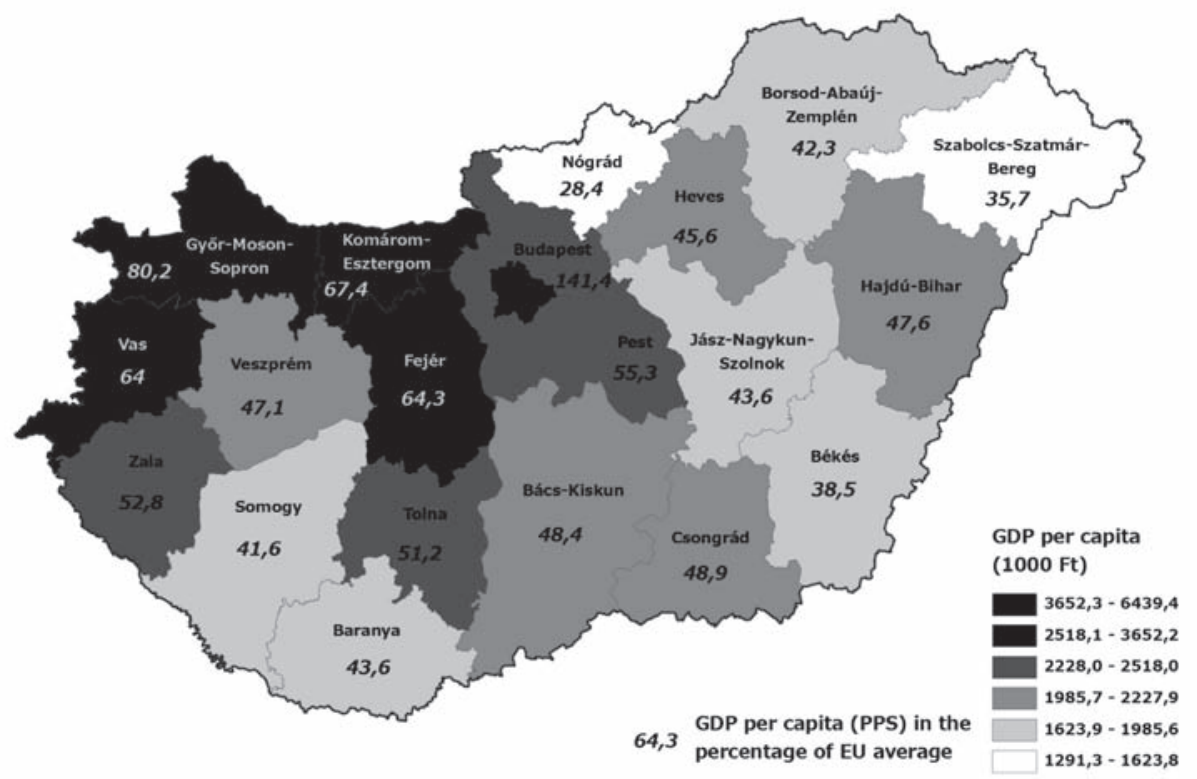

Figure 4. Per-capita GDP and its ratio relative to the EU average in the NUTS3 level counties of Hungary in terms of purchasing power parity (PPS), 2013 (Based on KSH data, map prepared with the support of J Gutpintér)

and the aspects of territoriality are more integrated - as Péti pointed out in his work (Péti, 2014). Transportation - primarily: highway - development projects implemented for the most part with EU funding from accession have also failed to bring about the expected spectacular economic benefits in the rural regions. For example, the disadvantaged regions that have become accessible through the extended M3 and M6 highways in Baranya, Borsod-Abaúj-Zemplén and HajdúBihar counties are not showing signs of growing economic dynamics, indeed, the Budapest-centered large infrastructure development projects may indeed have, in many cases, enhanced the agglomerational advantages of the region of Budapest over the rest of the country (see Figure 4).

\section{Core-Periphery, the Dominant Pattern in the Spatial Structure of Hungary}

In the economic spatial structure of Hungary, the core-periphery dichotomy appears most pronouncedly among the EU countries. Forty percent of the GDP is generated, and two thirds of research and development $(\mathrm{R}+\mathrm{D})$ capacity is located 
in Budapest, while only 18 percent of the total population lives there. Obviously this situation has a particular historical background: at the end of the World War I, Hungary lost two third of its territory including all the major regional urban centers that could theoretically have counterbalanced Budapest. Several strategies (governmental concepts of 1971, 2005 and 2014) attempted since at developing momentous urban centers in the countryside but they could never achieve real results. Since the EU accession this duality between the capital and the rest of the country has further risen. Budapest has been able to improve its international importance and become one of the most interesting, vibrant focal point of this part of Europe. Hungary's monocentric territorial structure, the overly Budapestcentered transport system, the lack of transversal links or even the deficiencies of the settlement network, impede the economic development in rural regions while this structure is not even beneficial for Budapest beyond a certain point. The excessive concentration of the economy - primarily in Budapest and a handful of other regions - may result in massive losses in efficiency, e.g. as a consequence of the scarcity of available commercial sites, transport, the increasingly concentrated environmental burdens, commuting and the costs of the treatment of economically depleted rural areas.

\section{The Impact of Crisis on Regional Disparities}

As I have mentioned, on the general EU level the crisis suspended the reduction in regional disparities that had taken place until 2009. In Hungary the process of divergence of regions that had continued practically unbroken since the EU accession seemed to be grinding to a halt in the wake of the 2008-2009 economic crisis; indeed, a process of leveling among regions was also observed in certain years (see Figure 5). According to the territorial GDP and investment statistics released for the period up to 2012, the decrease in territorial inequalities has not so much been driven by dynamic convergence of the lagging regions as by a deceleration in the growth of the most advanced regions. This is because it was the most advanced counties that were hardest hit at that time by the economic crisis which affected each county to different extents, i.e. the regions with the highest proportions of foreign direct investment, whose output was most heavily exposed to the quickly responding external demand as well as to retail consumption and investment demand driven largely by currency loans. It was primarily the highly developed Western and Central Transdanubian regions that were hit hardest by the economic downturn in 2009. Nonetheless, the three most developed regions - Central Hungary, Western Transdanubia and Central Transdanubia - with 24 percent of Hungary's total population, still generated two-thirds of Hungary's GDP, and some 89 per cent of foreign direct investments that can be geographically 




Note: The index measures the territorial distribution of GDP relative to the territorial distribution of the population. Its value range: 1-100 (1 = no territorial difference).

Figure 5. Developments in the territorial inequality of GDP at the county level, on the basis of the Hoover index (based on KSH data)

localized was operating in businesses having their registered offices in these regions. From 2010 the economic weight of Budapest within Hungary started to decrease, even if only to a slight degree. On the other hand, Pest county, comprising the agglomeration of the capital city, has been gradually falling back since 2008 not only in absolute terms, but also in the ranking order of the counties, despite the fact that up to 2007 it seemed to be on the way to becoming a dynamic region linked to Budapest. During the pre-crisis years the intensive residential construction boom in the Budapest agglomeration resulted in strong suburbanization that was partly a consequence of the growth in the provision of foreign currency loans; due to this, tensions are particularly strong in this region. We cannot judge yet whether this change in regional development dynamics is a real turning point or only a temporary leveling effect of the recession.

\section{Conclusions}

In spite of the modest and decelerating convergence of Eastern Central Europe we see that the post socialist EU members have not been able to attain the economic development and welfare level of the West, and there is not an observable trend of doing that within reasonable time. Only the most developed regions, 
typically the capitals could exceed the EU average measured at purchasing power parity. However in several dimensions the regions of these countries are depending on the western economies or on the European Union as such. In several socioeconomic terms, such as health, the difference between the East and the West of the EU is still very sharp, while demographic trends with increasing westward migration patterns resulting in loss of labor force may threaten the future economic development of eastern EU countries. What is more, most of the eastern bloc countries have become regionally more fragmented in terms of economic prosperity, quality of life by today as a result of a regional divergence within countries. Economic transition and EU integration were followed by imbalanced regional development as a result of the dominant role of the foreign direct investments in regional development, which led to the concentration and increase of territorial inequalities within these countries. The economic crisis has exerted a territorially diverse influence that has modified regional development, e.g. by increasing the importance of difference between North and South. The crisis has seemed to slow down or even stop this spatial concentration in Hungary.

In spite of the higher growth potential of the eastern part of the EU there is a risk that without changes its periphery position will be conserved in longer term. However, the recent economic recession indeed launched changes.

\section{References}

ESPON. 2005. Urban areas as nodes in a polycentric development. ESPON Project 1.1.1. Available at: http://www.espon.eu/main/Menu_Projects/Menu_ESPON2006Projects/Menu_Thematic Projects/

ESPON. 2010. Demographic and migratory flows affecting European regions and cities. (DEMIFER). Available at: http://www.espon.eu/main/

European Commission. 2014. Investment for jobs and growth - Promoting development and good governance in EU regions and cities: Sixth report on economic, social and territorial cohesion. Brussels: European Commission.

EUROSTAT. 2015. Newsrelease Euroindicators, 140/2015. Eurostat Press Office. Available at: http://ec.europa.eu/eurostat/documents/2995521/6940166/2-14082015-AP-EN.pdf/660ae7cbbb7d-4905-a78f-64034b4b659b

Magyar Nemzeti Bank (MNB). 2014. Növekedési jelentés. Budapest: Magyar Nemzeti Bank.

Péti, Márton. 2014. A területfejlesztés és gazdaságfejlesztés megújításának újabb lépése: Magyarország Partnerségi Megállapodása 2014-20. Falu Város Régió, 2, 12-22.

Salamin, G. and Sütő, A. 2011. Changing territorial structures of the EU. In Salamin, G., Radvánszki Á., Drahos, Zs. (eds) 2011. The Territorial State and Perspectives of the European Union. Budapest: Hungarian EU Presidency, 50-63. Available at: http://ec.europa.eu/regional_policy/ index.cfm/en/policy/what/territorial-cohesion/

United Nations. 2015. World Urbanization Prospects - The 2014 Revision. New York: United Nations.

Wallerstein, Immanuel. 2010. Bevezetés a világrendszer-elméletbe. Budapest: Harmattan Kiadó. 